\title{
Cyber Counseling : Solusi Konseling di Masa Pandemi
}

\author{
Mariana Puspa Sari*, Herdi Herdi \\ Magister Bimbingan dan Konseling, Fakultas Ilmu Pendidikan, Universitas Negeri Jakarta \\ *Corresponding Author. Email: MarianaPuspaSari_1108820009@mhs.unj.ac.id
}

\begin{abstract}
This study aims to explore the role of cyber counseling during the pandemic for Counseling Guidance Teachers and students. This type of research is a literature study or library research using secondary data sources collected through textbooks, e-books, scientific articles, websites, and other sources relevant to the research problem. The data of this study were analyzed descriptively qualitatively. The results of this study indicate that through onlinebased BK services, students and BK teachers/Counselors can be mutually facilitated because there are many opportunities and benefits available in an effort to support the achievement of counseling goals. The presence of cyber counseling as a counseling solution during the pandemic is expected to be able to help solve student problems at this time.
\end{abstract}

\begin{abstract}
Abstrak: Penelitian ini bertujuan untuk mengeksplor peranan cyber counseling di masa pandemi bagi Guru Bimbingan Konseling dan peserta didik. Jenis penelitian ini adalah studi literatur atau penelitian kepustakaan dengan menggunakan sumber data sekunder yang dikumpulkan melalui buku teks, $e$ book, artikel ilmiah, website, dan sumber-sumber lain yang relevan dengan masalah penelitian. Data penelitian ini dianalisis secara deskiriptif kualitatif. Hasil penelitian ini menunjukkan bahwa melalui layanan BK berbasis online, peserta didik dan guru BK / Konselor dapat saling difasilitasi karena banyak peluang dan manfaat yang tersedia dalam upaya mendukung tercapainya tujuan konseling. Hadirnya cyber counseling sebagai solusi konseling di masa pandemi diharapkan mampu membantu terentaskannya masalah peserta didik saat ini.
\end{abstract}

\section{Article History}

Received: 02-07-2021

Revised: $12-08-2021$

Accepted: 06-09-2021

Published: 05-10-2021

\section{Key Words: \\ Cyber Counseling, Guidance And Counselin, Pandemic Covid-19.}

\section{Sejarah Artikel \\ Diterima: 02-07-2021 \\ Direvisi: 12-08-2021 \\ Disetujui: 06-09-2021 \\ Diterbitkan: 05-10-2021 \\ Kata Kunci: \\ Cyber Counseling, Layanan BK, Pandemi Covid-19.}

How to Cite: Sari, M., \& Herdi, H. (2021). Cyber Counseling : Solusi Konseling di Masa Pandemi. Jurnal Paedagogy, 8(4), 579-585. doi:https://doi.org/10.33394/jp.v8i4.3949

\section{Pendahuluan}

Revolusi 4.0 berdampak terhadap disrupsi di sektor teknologi, hukum, ekonomi, pertanian serta kehidupan sosial lainnya, termasuk sektor pendidikan (Firman, 2019). Pendidikan menjadi salah satu bidang yang mencoba meningkatkan peranan teknologi sebagai penunjang dalam meningkatan efektifitas hasil kerja. Optimalisasi serapan peserta didik terhadap materi pembelajaran diharapkan bisa lebih baik dengan mengandalkan teknologi. Salah satu perwujudannya adalah dengan pemanfaatan media-media pembelajaran berbasis komputer. Karena pandemi Covid-19, di Indonesia setidaknya hampir seluruh kegiatan belajar dari jenjang sekolah dasar hingga pendidikan tinggi di alihkan menjadi sistem daring atau online (Kasih, 2020). Covid-19 membuat sebagian orang merasa cemas khawatir tertular penyakit dari interaksi yang mereka lakukan (Chodijah et al, 2020). Berbagai macam aturan dan protokol kesehatan yang baru mengharuskan semua orang untuk tidak melakukan kontak sosial secara langsungsekalipun dalam kegiatan pembelajaran. Hal tersebut juga mempengaruhi psikologis anak atau peserta didik yang tidak terbiasa melakukan pembelajaran secara online (Syah, 2020; Asmuni, 2020). 
Permasalahan yang dihadapi oleh peserta didik pada saat ini cukup kompleks, di mana perpaduan dari permasalahan sudah ada sebelum kondisi pandemi covid-19 diperparah dengan kondisi saat ini. Permasalahan tersebut diantaranya: gangguan psikologis dan kecemasan yang berlebihan di masa pandemi yang bisa menghambat peserta didik dalam menjalani proses belajar, kebiasaan belajar yang menurun atau rendah (Harahap, 2020), kecemasan mengenai virus corona dan perubahan belajar dari offline ke online (Fitria dkk, 2020) dan proses adaptasi cara belajar online (Tirto, 2020). Guru bimbingan dan konseling sebagai garda terdepan dalam memberikan layanan yang sesuai dengan permasalahan siswa. Bimbingan dan konseling merupakan layanan bantuan untuk peserta didik, baik secara perorangan maupun kelompok agar mandiri dan berkembang secara optimal, dalam hal ini guru BK memberikan layanan yang berkaitan dengan pengembangan dan pengarahan di bidang pribadi, sosial, belajar dan karir dengan tujuan untukmemandirikan peserta didik atau siswa (Flurentin, 2016; Yusuf, 2006). Layanan bimbingan dan konseling bertujuan untuk mengarahkan individu agar dapat melaksanakan kegiatan pembelajaran yang efektif dan efisien (Prayitno, 2017).

Namun di tengah pandemi ini muncul kebiasaan baru atau"New Normal" yang mengacu pada perubahan perilaku manusia termasuk membatasi kontak person-to-person seperti berjabat tangan dan harus menjaga jarak minimal 2 meter (Kompasiana, 2020). Sejalan dengan upaya pemerintah melalui Kementerian Pendidikan dan Kebudayaan yang tertuang dalam Surat Edaran No. 2 Tahun 2020 tentang Pencegahandan Penanganan Covid19 di Lingkungan Kemdikbud, serta Surat Edaran No. 3 Tahun 2020 tentang Pencegahan Covid-19 pada Satuan Pendidikan (Ratriani, 2020). Pembatasan kontak person-to-person tersebut tentu dapat mengganggu khususnya bagi guru bimbingan dan konseling dalam memberikan layanan kepada konseli. Dalam mengupayakan tercapainya proses bimbingan dan konseling yang optimal di masa pandemi seperti saat ini maupun di masa yang akan datang, Guru BK dituntut untuk terus mengupgrade diri baik dari segi keilmuan dan juga kemampuan menggunakan perangkat komputer. Konselor maupun guru BK perlu memahami dan menguasai kehadiran berbagai media"baru", serta dapat memanfaatkan media baru tersebut untuk mendukung pelaksanaan bimbingan dan konseling yang akurat, profesional dan tetap menjaga kaidah nilai-nilai budaya yang berkembang di tengah masyarakat (Nursalim, 2017).

Dampak dari perubahan cara belajar karena situasi pandemi harus direspon secara tepat dan cepat. Hal tersebut melahirkan kolaborasi untuk menciptakan pelayanan bimbingan dan konseling komprehensif berbasis online (Corey, 2017). Lonjakan pesat dalam penggunaan teknologi digital berkemampuan internet telah mengubah cara orang berkomunikasi, memperoleh informasi, dan telah menyediakan alternatif untuk penyediaan layanan konseling. Eksistensi bimbingan dan konseling merupakan salah satu dari tiga komponen utama yang ada di sekolah dituntut untuk adaptif dengan segala perubahan yang ada (Flurentin, 2013). Salah satu inovasi dalam pelaksanaan layanan bimbingan dan konseling adalah layanan cyber counseling atau sering disebut konseling on line. Adapun penelitian ini bertujuan untuk mengeksplor peranan cyber counseling di masa pandemi bagi Guru Bimbingan Konseling dan peserta didik.

\section{Metode Penelitian}

Metode yang digunakan dalam penelitian ini adalah studi literatur yang dilakukan dengan membaca sumber-sumber kepustakaan untuk memperoleh data yang diperlukan (Arikunto, dalam Asmuni, 2020). Sumber data yang digunakan berasal dari data sekunder, dimana data 
sekunder tersebut dikumpulkan melalui buku teks, jurnal ilmiah, e-book, website, dan sumber-sumber lain yang relevan dengan masalah penelitian. Selanjutnya data yang dikumpulkan dianalisis secara deskriptif kualitatif.

\section{Hasil Penelitian dan Pembahasan}

Cikal bakal berdirinya cyber counseling berawal dari penyelenggaraan konseling on line pada dekade 1960-1970. Cyber counseling pertama kali muncul pada dekade 1960 dan 1970 dengan perangkat lunak dalam program Eliza dan (Koutsonika, 2009). Dalam pelaksanaannya ada beberapa istilah yang biasa digunakan untuk dalam penyebutan konseling online termasuk terapi online atau internet, konseling elektronik, terapi elektronik, terapi cyber, terapi menggunakan email, konseling berbasis web, konseling internet, konseling cyber, konseling sesi tunggal sinkron,dan terapi-e-mai (Li Lau, Jaladin, \& Abdullah, 2013).

Telepon telah digunakan untuk saluran darurat sejak 1950-an dan saat ini digunakan secara luas untuk layanan pembantu (Allerman, 2002; Centore \& Milacci, 2008; Mohr et al., 2008; Stead et al., 2013). Konseling melalui video telah digunakan sejak tahun 1960-an (Holmes \& Foster, 2012; Rohland, 2001). Untuk masing-masing, ada padanan yang di mediasi komputer modern. Cyber counseling yang didefinisikan sebagai praktek konseling profesional yang terjadi ketika konseli dan konselor berada secara terpisah dan memanfaatkan media elektronik untuk berkomunikasi melalui internet (Petrus, 2017). Cyber counseling merupakan salah satu strategi yang dapat digunakan dalam proses pelaksanaan pemberian layanan Bimbingan dan Konseling (Petrus \& Sudibyo, 2017). Dengan kata lain dapat disimpulkan bahwa cyber counseling merupakan proses pemberian bantuan kepada konseli yang dilakukan secara on line atau melalui media komunikasi jaringan internet yang dilakukan di mana pun dan kapan pun atas persetujuan konseli dengan konselor sehingga dalam pelaksanaannya lebih efektif dan efisien.

Cyber counseling berkembang di Indonesia dengan cukup pesat, terutama sejak munculnya aplikasi-aplikasi jejaring sosial dalam bentuk zoom meeting, cloud, google meeting, google talk, line, whatsapp, email, facebook, danjenis aplikasi lainnya baik itu telephone seluler serta instan massaging. Cyber counseling telah menjadi sarana yang memungkinkan untuk membantu kaum muda ketika mereka menghadapi tantangan kesejahteraan emosional dan mental (Glasheen dan Campbell, 2008). Permintaan klien untuk layanan tersebut diharapkan meningkat secara dramatis di tahun-tahun mendatang karena aksesibilitas internet (Norcross, Hedges, \& Prochaska, 2002; Stamm, 1998; Wright, 2002). Sesuai dengan penjelasan sebelumnya, cyber counseling telah menjadi pilihan yang masuk akal untuk membantu kaum muda khsusunya peserta didik ketika mereka menghadapi tantangan kesejahteraan mental (Glasheen, Campbell, 2009) dan King et al. (2006).

\section{Media yang Digunakan dalam Cyber Counseling}

Beberapa media yang bisa digunakan diantaranya (Ifdil:2011) :

\section{1) Website/situs}

Dalam menyelenggarakan cyber counseling, Konselor dapat menyediakan sebuah alamat situs untuk melakukan praktik online, sehingga konseli yang ingin melakukan konselng dapat berkunjung ke situs tersebut.

2) Telephone/Handphone

Telepon telah digunakan untuk saluran darurat sejak 1950-an dan saat ini digunakan secara luas untuk layanan pembantu (Allerman, 2002; Centore \& Milacci, 2008; Mohr et 
al., 2008; Stead et al., 2013). Melalui telephone/ handphone konselor dan konseli bisa saling terhubung guna berkomunikasi dalam pengentasan masalah.

3) Email

Cyber counseling dalam bentuk email dimulai pada pertengahan 1990-an; sekitar waktu yang sama, situs psikoedukasi juga mendapatkan popularitas. Pertumbuhan konseling online ini difasilitasi oleh perkembangan hardware dan software, teknologi komunikasi berbasis internet dan desain web yang membuat komunikasi jarak jauh menjadi efektif dan nyaman (Grohol, 1999, 2004).

4) Chat/Instan Messaging dan Jejaring Sosial

Percakapan ini bisa dilakukan dengan saling berinteraktif melalui teks, maupun suara dan video. Aplikasi dapat digunakan untuk chatting seperti skype, messenger, dan google talk dan juga melalui jejaring sosial seperti facebook, dan twitter. Dalam kasus konseling berbasis teks, riwayat obrolan dapat disimpan dan tersedia untuk konsultasi nanti, yang memungkinkan klien membaca ulang, melatih, dan memperkuat solusi yang didiskusikan dengan konselor (Rochlen, Zack, \& Speyer, 2004).

5) Video Conferencing

Konseling melalui video telah digunakan sejak tahun 1960-an (Holmes \& Foster, 2012; Rohland, 2001). Video Conferencing merupakan pertemuan melalui video, dibantu oleh berbagai macam media jaringan seperti telepon atau media lainnya yang digunakan untuk transfer data video, di dalam sudah menyediakan fasilitas video call.

\section{Tahapan Cyber Counseling}

Meski dilakukan secara on line, proses konseling dengan model ini memiliki tiga tahapan penyelenggaraan (Ifdil:2011) yaitu :

1) Tahap Persiapan

Mencakup aspek teknis penggunaan perangkat keras (hardware) dan perangkat lunak (software). Selain itu kesiapan konselor pada aspek keterampilan, kelayakan akademik, penilaian, secara etik, hokum dan lainnya.

2) Tahap Proses

Tahapan cyber counseling tidak jauh berbeda dengan tahapan proses konseling langsung (Prayitno : 2004). Tahap-tahap yang dilakukan yakni: tahap pengantaran, penjagaan, penafsiran, pembinaan dan penilaian. Namun dalam pelaksanaanya "kontinum flesksibel". Pada sesi cyber counseling lebih menekankan pada terentasnya masalah konseli dengan cara melakukan bentuk pendekatan, teknik atau terapi yang digunakan.

3) Tahap Pasca

Ada tiga yaitu di pasca proses cyber counseling, antara lain:

a) Konseling akan sukses dengan ditandai dengan kondisi klien yang KES (effective daily living- EDL)

b) Konseling akan dilanjutkan ada sesi tatap muka (Face to Face-FtF)

c) Konseling akan dilanjutkan pada sesi cyber counseling berikutnya dan

d) Konseli akan direferal pada Konselor lain atau ahli lain.

\section{Kelebihan dan Kelemahan Cyber Counseling}

Kelemahan cyber counseling antara lain: konselor sering ragu-ragu untuk memanfaatkan kemajuan teknologi (Green-Hamann et al., 2011; Holmes \& Foster , 2012; McAdams \& Wyatt, 2010; West \& Hanley, 2006). Hal ini disebabkan oleh kurang cakapnya konselor dalam pemanfaatan teknologi. Selain itu, kebutuhan data non-verbal dengan 
mengamati bahasa tubuh dan petunjuk visual dan verbal lainnya akan mengubah dinamika konseling (Barak et al., 2009; Cartreine dkk., 2010; Suler, 2004).

Kelebihan dari cyber counseling adalah media seperti facebook, instagram, skype, twitter, whatsapp tersebut mudah digunakan, memiliki asas kerahasiaan, praktis, dan dapat diakses dari mana saja (Sutijono, 2018). Terlebih lagi media tersebut dapat diaplikasikan dalam layanan bimbingan dan konseling. Oleh karena itu, cyber counseling menjadi pilihan bagi para peserta didik untuk mengkonsultasikan problem mereka. Mengenai efektivitas dari cybercounseling dinyatakan bahwa efektivitasintervensi online serupa dengan intervensi tatap muka (Barak, Hen, Boniel-Nissim, \& Shapira, 2008).

Kelebihan kedua dari cyber counseling, yaitu Konseli dan konselor tidak harus bertemu satu sama lain dalam ruang fisik, dengan cara seperti itu keduanya tidak harus bepergian, terikat janji temu, dan mengeluarkan biaya untuk sampai di suatu tempat (Abney \& Cleborne, 2004; Cartreine et al., 2010; Green-Hamann et al., 2011). Kelebihan berikutnya, konseli dapat mencari layanan dengan cara yang anonimitas (Barak et al., 2008). ; Cartreine et al., 2010; McAdams \& Wyatt, 2010). Ini dapat membantu konseli merasa lebih aman dan memiliki efek fasilitasi dalam membangun dan mempertahankan aliansi terapeutik (Harris \& Birnbaum, 2014).

Layanan cyber counseling melalui email juga memungkinkan konseli untuk merujuk ke surat elektronik mereka ketika masalah yang sama terulang (Alleman, 2002; Caudron, 1998; Cook \& Doyle, 2002; Robson \& Robson, 2000). Kemudahan merujuk ke email dapat membantu konseli mengatasi masalah mereka dengan cepat. Melalui layanan cyber counseling yang bersifat tertulis. Membantu proses eksplorasi diri konseli dan menjadi salah satu terapi untuk mereka (Caudron, 1998; Hall, 2004; Oravec, 2000; Robson \& Robson, 2000). Berkaitan dengan kebaikan layanan Cyber-conseling, konselor sekolah dapat memanfaatkan keunggulan internet ini untuk mendekatkan dirinya dengan guru, orang tua dan siswa. Hal ini sejalan dengan salah satu peran konselor, untuk mengkombinasikan sumber daya untuk memaksimalkan perluasan layanannya. Kebijaksanaan konselor menggabungkan keterampilan membantu Internet untuk membangun lingkungan kolaboratif antara siswa, guru dan orang tua (Amir Awang, 2007).

\section{Peranan Cyber Counseling di Masa Pandemi}

Cyber counseling dinobatkan sebagai cara terbaik untuk menawarkan layanan konseling selama wabah Covid-19. Karena konseli dan konselor tidak harus bertemu satu sama lain dalam ruang fisik, dengan cara seperti itu keduanya tidak harus bepergian, terikat janji temu, dan mengeluarkan biaya untuk sampai di suatu tempat (Abney \& Cleborne, 2004; Cartreine et al., 2010; Green-Hamann et al., 2011). Dengan tidak bertemu secara langsung penyebaran virus akan bisa diminimalisir dan kesehatan fisik keduanya juga tetap terjaga.

Cyber counseling juga menjadi sarana yang memungkinkan untuk membantu kaum muda dalam hal ini peserta didik ketika mereka menghadapi tantangan kesejahteraan emosional dan mental (Glasheen dan Campbell, 2008). Berkembangnya aplikasi-aplikasi jejaring sosial berbasis internet adalah sarana yang digunakan dalam konseling model ini. Di mana saja dan kapan saja, mereka bisa berinteraksi dengan pemberi bantuan psikologis, membuat jadwal konseling atau melakukan beberapa sesi proses konseling. 


\section{Kesimpulan}

Kesimpulan dari hasil penelitian ini bahwa melalui layanan BK yang diberikan berbasis online, peserta didik dan guru BK / Konselor dapat saling difasilitasi karena banyak peluang dan manfaat yang tersedia dalam upaya mendukung tercapainya tujuan konseling. Informasi yang dibutuhkan dapat diakses kapan saja dan di mana saja bila diperlukan, dapat diunduh dan digunakan secara offline, digandakan dan didistribusikan menggunakan alat pendukung elektronik. Kunci untuk mewujudkan hal tersebut terletak pada integrasi yang mulus dari beberapa program perangkat lunak dan jangkauan kekuatan Internet yang jauh. Sebagian besar peserta didik di sekolah saat ini telah memanfaatkan teknologi informasi melalui internet dalam kehidupan sehari-hari.

Beberapa kelebihan dari cyber counseling dan juga kelemahannya bisa menjadi pertimbangan bukan hanya untuk peserta didik dan guru BK selaku konselor sekolah. Tetapi juga orang tua dan pemangku kebijakan untuk membuka peluang seluas-luasnya terhadap perkembangan teknologi dalam dunia pembelajaran juga kebermanfaatannya bagi sesama. Di tengah situasi kesehatan fisik yang tak menentu, jangan sampai kesehatan mental generasi muda khususnya peserta didik ikut terganggu. Hadirnya cyber counseling sebagai solusi konseling di masa pandemi diharapkan mampu membantu terentaskannya masalah peserta didik saat ini.

\section{Saran}

Adapun saran yang disampaikan yakni bagi peneliti berikutnya akan lebih baik jika meneliti efektivitas dari masing-masing media yang digunakan dalam cyber counseling agar lebih dapat mendalami kebermanfaatannya.

\section{Daftar Pustaka}

Alfan Kurniawan, Nanda. (2019). Profil konselor Madiun dengan nilai cinta di Era Society 5.0 (Maya, Direktif, Unik). Jurnal Nusantara Of Research. 2019, Vol. 6, No. 1, 115.

A.Sabella, Russell and Beverly L. Booker. (2018). Using Technology to Promote Your Guidance and Counseling Program Among Stake Holders. International Journal of Contemporary Applied Researches. Vol. 5, No. 11. 206 -213.

A. Zaimatus Septiana, Nila. (2020). Perilaku Prososial Siswa SMP Di Era Revalusi Industri 4.0 (Kolaborasi Guru dan Konselor). Jurnal Inovasi Teknologi Pendidikan Volume 7, No. 1, April 2020 (93-104).

Asmuni, A. (2020). Problematika Pembelajaran Daring di Masa Pandemi Covid-19 dan Solusi Pemecahannya. Jurnal Paedagogy, 7(4), 281-288. doi:https://doi.org/10.33394/jp.v7i4.2941

Biondi Situmorang, D. (2020). On Line/Cyber Counseling Service in Covid-19 Outbreak: Are They Really New?. Journal of Pastoral Care and Counseling Vo. 74 (3). Pg. 166-174.

Chodijah, M., Nurjannah, D. S., Yuliyanti, A. Y., \& Kamba, M. (2020). SEFT sebagai terapi mengatasi kecemasan menghadapi Covid-19. Karya Tulis Ilmiah LPPM UIN Sunan Gunung Djati Bandung.

Cipolletta, Sabrina dan Damiano Mocellin. (2017). Online counseling: An exploratory survey of Italian psychologists' attitudes towards new ways of interaction. Psychotherapy Research. 
Fang, Lin, etc. (2017). Undergraduate Student Experiences with Text-Based Online Counselling. British Journal of Social Work (2017) 0, 1-17.

Fariyatul Fahyuni, Eni, dkk. (2019). Model aplikasi cybercounseling Islami berbasis website untukmeningkatkan self-regulated learning siswa SMA. Advances in Social Science, Education and Humanities Research, volume 382.

Firman. (2019). Strategi dan Pendekatan Pelaksanaan Bimbingan Konselingdi Sekolah untuk Menghadapi Revolusi Industri 4.0. Jurnal ABKIN.

Kurniawan, Dydik, Ardi Indra Lukmana dan Tri Wahyuningsih. (2020). Pengembangan Aplikasi Absensi Siswa Berbasis Androiddi Pusat Informasi \& Bimbingan Konseling Sekolah Menengah Kejuruan SAMARINDA. Jurnal Bimbingan dan Konseling Islam. Vol.10, No. 01, Juni 2020, Hal. 55-68.

Luthfiah Kirana, Dyah. (2019). Cyber Counseling Sebagai Salah Satu Model Perkembangan Konseling Bagi Generasi Milenial. Prosiding SNBK (Seminar Nasional Bimbingan dan Konseling) Vol. 3 No.1.

Mega, Nur, dkk. (2021). E-Councelling dalam Menangani Kasus Bullying di Sekolah. Jurnal Sipatokkong BPSDM Sulawesi Selatan. Vol. 2 No. 1.

Paterson, S. M, T. Laajala and P.-L. Lehtelä. (2017). Counsellor students' conceptions of online counselling in Scotland and Finland. British Journal of Guidance \& Counselling, British Journal of Guidance \& Counselling.

Setiawan, Andi. (2016). Peranan Teknologi Informasi dalam Bimbingan dan Konseling. Bitnet Jurnal Pendidikan Teknologi Informasi, Volume 1 Nomor 1, (46-49).

Sumarwiyah, Edris dan Zamroni. (2017). Pemanfaatan Tekonologi Informasi (TI) Dalam Layanan Bimbingan Dan Konseling Sebagai Representasi Berkembangnya Budaya Profesional Konselor Dalam Melayani Siswa. Program Studi Bimbingan dan KonselingUniversitas Muria Kudus VOLUME: 2/ Nomor 1.

Tania, Isna, Yarmis Syukur dan Triave Nuzila Zahri. (2019). Student's Problems Learning and Guidance Counseling Services in the Era of Industrial Revolution 4.0. 5th International Conference on Education and Technology (ICET 2019).

Tirel, Maili , etc. (2019). When Do People Seek Internet Counseling?Exploring the Temporal Patterns of Initial Submissions to Online Counseling Services. Journal of Technology in Human Services.

Tjalla, Awaluddin, Herdi dan Cecep Kustandi. Green education-based model online career counseling "ACIS-Q" to enhance career maturity of vocational schoolsstudents.

Tjalla, Awaluddin, Herdi and Cecep Kustandi. (2015). The Influence Of Online Carreer Counseling"ACIS-Q" The Vocational Secondary High School Student's (SMK) Carrer Maturity Of In The Province Of Jakarta, Indonesia. International Journal of Research Studies in Psychology. Volume 4 Number 1, 37-43.

Zarirah, Meithy Intan dan Herdi. (2017). Kompetensi Teknologi pada Guru BK. Journal INSIGHT. 